\title{
Digital detox tourism against post-modernity
}

\author{
Ipek Itir Can, Nurhayat Iflazoglu*
}

\author{
Keywords: \\ Digital detox, \\ Digital detox tourism, \\ Alternative tourism, \\ Post-modernism.
}

\begin{abstract}
Technology has become an integral part of daily life. Although developments in the digital world offer many advantages to users, researches show that the use of smart devices is rapidly turning towards a kind of an addiction (digital addiction) in every field. In such unwanted situations, people try to apply a kind of a purification program by staying away from technological devices for a certain period of time with "Digital Detox". Transferring the need for digital detox to people's holiday experience and thus providing a kind of a technological purification during the holiday periods can be called "Digital Detox Tourism". Digital detox tourism, which is against post-modernism, attracts attention as a type of tourism preferred by individuals who seek diversity and have different expectations, especially those who want to stay out of intensive technology-based tourism activities. Perceived as fairly new concept in literature that has emerged as a result of the changing tourists expectations, establishing the theoretical infrastructure of digital detox tourism on the axis of post-modernism, evaluating the factors that caused the emergence of digital detox tourism, examining the factors that drive people to digital detox tourism and examination of theoretical and practical work about digital detox tourism; constitute the aim of this study. This study is aimed at researchers and target marketing organizations as it offers valuable conclusions that help better understand the emotions of individuals who are involved in or are avoiding digital detox tourism. Understanding what triggers positive and negative emotions of individuals is thought to help service providers develop their products and marketing strategies.
\end{abstract}

Article History:

Submitted: 29.08.2020

Accepted: 11.12 .2020

Doi: https://doi.org/10.31822/jomat.801813

\section{Introduction}

Since the late 1990s and early 2000s, the intense use of computers, internet and technology was seen as a pathology for the first time, and American scientists called this pathology "internet addiction" (Reed, 2002). Internet addiction is included as a pathology in the DSM-V, which was written by the American Psychiatric Association in 2013 and referred to as the Diagnostic and Statistical Manual of Mental Disorders (APA, 2013). Today's media uses this term too often, and constantly reports that what the digital world offers is a great danger especially to children (Kardaras, 2016). Developments in the digital world offer many advantages to users; when the use of social media, smartphones and internet games comes to the point of interfering with people's lives and relationships, various problems are encountered. In fact, in cases where internet use is not possible, as a result of not being able to prevent the desire to use the internet excessively, people experience tension and "digital addiction" may develop. Although it is an unresolved subject of discussion in the literature whether behavioral addictions can be evaluated as substance-related addictions, research has been conducted on many issues related to digital addiction, from smartphones to social media use and internet games.

According to the results of a study conducted in 2011 by the British consumer research firm Intersperience, the internet addiction is stated as an increasing risk (Murphy, 2011). In various studies -with the participation of studentsconducted by the University of Maryland (2010), the International Center for Media and the Public Agenda and the Intersperience Research Company (2011), it was noted that participants who were offline for 24 hours showed withdrawal symptoms. In addition, emotional symptoms such as feeling sad and lonely as well as physical addiction symptoms such as tremors, headaches and chills were observed in the participants, similar to smokers and coffee consumers trying to quit their habits. Addiction to the internet, which is used as a socialization tool, can develop as a pathological process (White, 2013). In such unwanted cases, it

\footnotetext{
"Corresponding Author $\quad$ Review Paper

Ipek Itir Can: Res. Asst., Anadolu University, Faculty of Tourism, Department of Tourism Management, Turkey, E-mail: ipekic@anadolu.edu.tr, Orcid Id:0000-0003-4793-7151 (iD)

Nurhayat Iflazoglu: Lecturer, Hatay Mustafa Kemal University, School of Tourism and Hotel Management, Department of Gastronomy and Lecturer, Hatay Mustafa Kemal University, School of Tourism and Hotel Management, Department
Culinary Arts, Turkey, E-mail:nurhayat.iflazoglu@mku.edu.tr, Orcıd Id: 0000-0003-4736-789X (iD) 
is recommended that people apply a kind of a purification program with "digital detox" by staying away from technological devices for a certain period of time. The word detox is used mostly regarding food and drinks and means keeping the body away from toxic or harmful substances for a certain period of time. Today, this term is combined with the concept of digital and is used for purification from the harmful effects of modern technology. "Digital Detox" first entered the Oxford dictionary in 2013 and has been used with this name in many sources since then (Syvertsen \& Enli, 2020). There are many reasons for the term digital detox to be included in the literature. The first of the aforementioned reasons is the feeling of depression due to the excessive use of technology (Booth, 2015). The use of technology everywhere and in every field creates a pressure on a person and this intense pressure can turn into stress and lead to burnout syndrome (Haber, 2013). Another reason is that a person cannot allocate enough time for his/her immediate environment due to intense use technology. Due to the intense use of digital devices, people both cannot spare enough time for the people they come together with and cannot receive enough attention from other people for the same reason. The intensive use of technology also causes the feeling of not being able to spend enough quality time with their loved ones (Magee, 2016). The result of a study conducted by the Paw Research Center in 2015 also supports these reasons. According to the research carried out in the USA, $89 \%$ of participants stated that they use their phones when they socialize, and $82 \%$ stated that they think that phone use has a negative effect on their current social communication (Rainie \& Zizkuhr, 2015).

Although the reflections of post-modernism on tourism are dependent on intense technology, the needs and expectations of the individuals participating in a touristic activity may differ. In other words, while some tourists prefer to have a touristic experience with virtual reality or augmented reality applications; some tourists may also seek different, unique experiences, and peak experiences (Quan \& Wang, 2004). Digital detox tourism, which is against post-modernism, attracts attention as a type of tourism preferred by individuals who seek diversity and have different expectations, especially those who want to stay out of intensive technology-based tourism activities. In the post-modern world, although the research on the concept of digital detox tourism, which seems attractive for tourists who want to enjoy their holidays regardless of technology, is increasing, it is seen in the relevant literature that it is limited in number. Therefore, this research, designed as a theoretical study, aims to reveal the theoretical framework of the concept of digital detox tourism. This research also emphasizes the importance of digital detox tourism for destinations and tourism practitioners; suggestions are presented that future research can reveal the premises and results of digital detox tourism.

\section{Literature Review}

\section{Tourism in Light of Post-Modernism}

Although the concepts of post-modernism and postmodernity, which started to manifest themselves in the world at the end of the 20th century and the beginning of the 21st century, initially appeared in the fields of art and architecture, they reached a wide spectrum over time and have influenced a wide range of sectors from manufacturing industry to service industry (Odabaşı, 2006; Güzel, 2014, Güneren \& Karakuş, 2015). The concept is formed by combining the words post (next, later) and modern (now, happening); "post-modern" means "after the modern era and/or state". Postmodernism fundamentally expresses a social, political, literary and political philosophy; where post-modernity describes the reflections of the related philosophy on society and culture. In this context, it would not be wrong to say that postmodernity is related to changes in conditions and/or institutions (Giddens, 1990).

Post-modernism movement born as a reaction to modernism when the basic principles of the philosophy of modernism that are promises of "enrichment, liberation, peace and happiness" were damaged by World War I and collapsed after World War II. In the modern period, also known as the age of reason, it was argued that all social problems could be solved and humanity would always progress through the union of human mind and science; in other words, the human mind and science were above all. However, due to the disasters of World War II, economic crisis and unhappiness, the idea of "social problems that can be easily solved with the human mind" defended by modernism has been corrupted and the belief in the human mind has been damaged. Thus, the understanding of modernism, which is characterized by rationality, positivism, science, reason and industry that produces standardized objects, has begun to leave its place to the understanding of post-modernism, which is characterized by diversity, heterogeneity, pluralism and fragmentation (Bilici, 2011). Globalization, consumerism, mass culture, 
individualization, commodified knowledge (commodification), information, and developing and transforming technology are the main factors that lead to the formation of the post-modern era. Lyotard (1997) explains post-modernism with the characteristics of societies after the Industrial Revolution. Features of post-modernism; questioning the concept of modernism, supporting globalization, accepting that there is no objective and single reality, criticizing uniqueness and defending diversity/pluralism. In the light of these features, it would not be wrong to say that postmodern society is a society of information, advanced technology, scientific knowledge and rapid change resulting from these developments (Sallan \& Boybeyi, 1994; Bozok, et al., 2014). In other words, it is seen that individuals adapt to change and their perspective on life has changed in the post-modern period. As a result of individuals' focus on a multicultural and consumption-oriented structure, a consumer society/consumption culture is formed and is rapidly developing, changes are experienced in value systems, the importance given to content leaves its place to form and for this reason, simulated images are created, reality transformations based on virtual simulation are experienced (Güzel, 2014). Firat and Shultz (1997), explain the effects of post-modernism on consumer behavior as "openness and tolerance, hyper-reality, continuity of the moment, unity of paradoxes, fragmentation, loss of commitment, decentralization of the subject, displacement of production and consumption, importance of style and form, and the acceptance of chaos and disorder". These concepts are defined by Firat and Shultz (1997) in Table 1 below.
Depending on the transformation process in individuals, it has become necessary to shape the goods and services offered to them, to create new supply sources and to ensure consumer orientation. For this reason, post-modernity has more or less started to show itself gradually in all sectors. For example, smartphone manufacturers have consciously or unconsciously - increased the amount of people's interest in their phones through the various functions they add to the devices. These developed functions can be counted as; logistic benefits (navigation), informative benefits (internet and mobile applications that deliver information) and relational benefits (social media channels) (Campbell \& Kwak, 2011). In a similar classification adapted to tourism, the functions are; facilitation (facilitating finding a place/direction in a new destination), searching for information (being able to obtain a lot of information about a destination via phone), communication (social media channels) and entertainment (mobile games, videos) (Wang, et al. 2014; Dickinson, et al. 2016).

Post-modernity in tourism is mainly characterized by the diversity of tourist experiences, motivations and touristic environments (Dujmović \& Vitasović, 2015; Dinçer, et al. 2018). Touristic consumers no longer want marketing with the "either this or that" approach, but rather "both this and that" approach; they also tend to focus on products and services that are unique to them and that can highlight their own differences. In this context, individuality, hyper-reality, virtual reality and surreal experiences and technology-oriented, unitbased touristic products and tourism types started to emerge in tourism (Kozak, et al. 2013).

Table 1: Brief Description of Post-modern Conditions

\begin{tabular}{|c|c|}
\hline Post-modern conditions & Brief descriptions \\
\hline Openness/tolerance & $\begin{array}{l}\text { Acceptance of difference (different styles, ways of being and living) without prejudice or evaluations of } \\
\text { superiority and inferiority }\end{array}$ \\
\hline Hyperreality & Constitution of social reality through hype or simulation that is powerfully signified and represented \\
\hline Perpetual present & Cultural propensity to experience everything (including the past and future) in the present, "here and now" \\
\hline Paradoxical juxtapositions & $\begin{array}{l}\text { Cultural propensity to juxtapose anything with anything else, including oppositional, contradictory and } \\
\text { essentially unrelated elements }\end{array}$ \\
\hline Fragmentation & $\begin{array}{l}\text { Omnipresence of disjointed and disconnected moments and experiences in life and sense of self - and the } \\
\text { growing acceptance of the dynamism which leads to fragmentation in markets }\end{array}$ \\
\hline Loss of commitment & Growing cultural unwillingness to commit to any single idea, project or grand design \\
\hline Decentering of the subject & Removal of the human being from the central importance \\
\hline Loss of commitment & Growing cultural unwillingness to commit to any single idea, project or grand design \\
\hline Decentering of the subject & $\begin{array}{l}\text { Removal of the human being from the central importance she or he held in modern culture - and the } \\
\text { increasing acceptance of the potentials of his/her objectification }\end{array}$ \\
\hline $\begin{array}{l}\text { Reversal of consumption and } \\
\text { production }\end{array}$ & $\begin{array}{l}\text { Cultural acknowledgement that value is created not in production (as posited by modern thought) but in } \\
\text { consumption - and the subsequent growth of attention and importance given to consumption }\end{array}$ \\
\hline Emphasis on form/style & Growing influence of form and style (as opposed to content) in determining meaning and life \\
\hline Acceptance of disorder/chaos & $\begin{array}{l}\text { Cultural acknowledgement that rather than order, crises and disequilibria are the common states of } \\
\text { existence - and the subsequent acceptance and appreciation of this condition }\end{array}$ \\
\hline
\end{tabular}


The concept of post-tourist was first explained by Feifer (1985) and three basic characteristics of post-tourists are mentioned in the definition (Urry, 1990). The first is that post-modern tourists do not have to leave their homes to see tourist attractions. This feature includes a reference to virtual reality and states that, thanks to increasing digitization and developing technology, the need to move in order to see and/or experience something disappears (Sağıroğlu, 2019), such as national parks, museums, domestic and international tourist destinations. Although post-tourists are often at home, they may feel like they are where they really want to be (Smith, 2003). The second is the desire of post-tourists to pursue a sense of pleasure. The third is that post-modern tourists have an opinion that there is no original tourist experience, that the tourist experience is meaningless, and that the tourism industry is a scripted and commodified game (Smith, 2003; Urry, 2009). The post-modern tourist is shaped by phenomena such as; search for freedom, connection established with symbols, authenticity, selfdiscovery, individuality, pleasure seeking, and longing for the past (Nuryanti, 1996; Blom, 2000; Muzaini, et al. 2007; Sağıroğlu, 2019).

Post-modern tourism leads to an increase in tourism types associated with surreal and virtual reality experiences; on the one hand, it is a type of tourism that contrasts with the meaninglessness of tourism types, makes use of technology on a high level, exhibits extreme individualistic features, and cares about sustainability (Kozak et al. 2013). Although post-modern tourism makes extensive use of technology and its benefits; there is evidence that some tourists do not like the digital collar and even feel stressed due to the expectations of being connected ( $\mathrm{Li}$, et al. 2018). These tourists are aware of the benefits of digitization; however, it is observed that they prefer face-to-face communication rather than online communication and even yearn for it. During their tourism experiences, they do not want to be online, on the contrary, they want to observe the destinations they visit in depth and to interact with the people there actively (Fan, et al. 2019). For this reason, the idea of realizing tourism experiences from where they sit at home via virtual reality is not attractive to the relevant tourist audience. Being aware of this situation and taking it into consideration, sector stakeholders - especially in accommodation businesses - have made an effort to offer appropriate touristic products to the masses who want to get away from digitization for a short time. This effort nowadays manifests itself with a hospitality experience that will provide tourists with the purification of digital devices; but day by day it expands its size from hospitality to a wider perspective. In other words, by moving beyond a hotel experience where digital devices are left at the reception during the entrance to the hotels (e.g. Healthouse Las Dunas hotel, Andalucía, Spain; Nayara Springs, Costa Rica; Pine Cliffs Resort, Portugal; The Surin Phuket, Thailand; Grenadines; Kimpton Monaco, Chicago, USA;JW Marriott Cancun, Mexico), there is no television in the rooms and no $\mathrm{Wi}-\mathrm{Fi}$ service is provided; on uninhabited islands where there is not even a base station, relaxing activities such as yoga and meditation are performed, noisy night entertainment or bustling music playing by the pool is replaced by special soft and soul calming music; it is possible to say that digital purification has gone beyond the boundaries of the hotel and has become a tourism experience in itself.

\section{Method}

The purpose of this research is to create a theoretical infrastructure of "digital detox tourism", to examine the digital detox tourism under post-modernism, to find the reasons why digital detox tourism is revealed, and to find the theoretical and practical researches for digital detox tourism. Under these circumstances in this research, an exploratory research model and a document review technique were used. In exploratory research, the first criteria are to reach and collect data from subsidiary sources. Yildırım and Şimşek (2013) stated that the main objective of a document review is to analyze written materials that contain information about the fact(s) to be investigated. Besides, according to Merriam (1988), all kinds of documents help the researcher to understand and discover the subject, and to eliminate the uncertainties about the research problem (Kıral, 2020). Document review can be used as a sufficient research method, especially when direct interviews and observations are not possible. In this direction, publications on digital detox and digital detox tourism were examined and a document analysis was made using the knowledge accumulated in the relevant literature. Best (1959) stated the document review technique as a systematic examination of existing records or documents as a data source (Karasar, 2005). Document review is carried out in five main stages: (1) accessing the documents, (2) checking the originality, (3) understanding the documents, (4) analyzing the data, and (5) using the data. The advantages of document review include the absence of reactivity, prolonged or time-spread 
analysis, individuality and specificity, quality, and (relative) low cost. On the other hand, the limitations of the document review are listed by Bailey (1982) as possible bias, accessibility, sampling bias, limited verbal behavior, lack of a standard format, and coding difficulty. Within the framework of the research, the written sources (books, articles, academic dissertations) and internet-based open access resources constituted the data source of the research.

\section{Findings}

\section{Digital Detox Tourism}

Human-technology interaction has recently become a love-hate relationship. Digitization has made our lives simultaneously significantly easier and more difficult. It has long been known that excessive use of digital displays can harm both our mental and physical health, and scientists have warned us about these issues for years (www.flogas.co.uk). Although it is an obvious fact that a mass dependent on it emerges as technology penetrates deeply into every aspect of our lives, there is also a mass that is aware of the negative effects of this addiction and wants to avoid it. Although the number of people who want to avoid negative effects is relatively less than the addicts today, it is thought that this rate will increase with the increase of awareness about the negative effects of technology in the future. There is a new type of tourism that has emerged to meet this need, and has made a name for itself in the last few years and ignores the intense technology that is at the basis of the post-tourism paradigm: Digital Detox Tourism. At the core of this type of tourism, this emerging holiday trend is often defined by the ubiquitous digital online-ism and disconnection from social media. Digital detox holidays are especially emerging as packages for disconnecting from digital devices (smartphones, laptops, tablets, etc.) and participating in detoxification therapies. A new form of technology is encountered in every trip or activity attended. Although 2009 and 2010 are known as the birth years of the digital detox vacation concept, the serious coverage of digital detox holidays in the media started in 2011. In 2016 and 2017, digital detox holidays have grown from a niche product to one that appeals to a wider consumer base (Pearce and Li Jing, 2018). That's why many vacationers around the world are looking for a vacation in the context of a digital detox vacation or "tech-free tourism" (www.flogas.co.uk). Some travel and tourism companies have begun to understand the challenges faced by their customers while on vacation and have begun to help them de-tech (www.verdict.co.uk). In addition, the rising trend of digital detox tourism, which inspires people to focus on themselves and nature, is located in various beautiful and tranquil locations around the world, stimulating people's desire to be included in this type of tourism.

When the related literature is examined; in a study conducted by Duncan (2014) in a museum where information and communication technologies were disconnected, it was observed that people experienced more mindful awareness, resulting in reduced stress and started to visit museums more often. Smith and Puczkó (2015) found that programs that keep people away from social media and digital devices reduce internet addiction, improve stress management, and increase their stamina in both work and daily life. As a result of Hoving's (2017) study investigating the reasons why Dutch tourists take digital detox holidays, it was determined that sociological, psychological, physical, technological, economic and geographical factors motivate tourists to take a digital detox holiday. Physical factors are physical health problems caused by excessive use of digital devices the MS (Multiple Sclerosis) disease, sleep problems, vision problems and obesity can be given as examples. Psychological factors include symptoms such as anger, tension, and depression that arise when there is no access to the internet and digital addiction. Sociological factors are exemplified as socialization problems that occur due to digital device addiction, problems arising in relationships with people, problems leading to divorce in marriage, and problems in business life. Technological factors refer to general problems from the need to show oneself to lack of concentration - created by channels such as an $\mathrm{e}^{-}$ book (electronic book) and social media channels that caused major transformations in the habits of Generation Z, usually born after 2000. Economic and geographical factors; although not directly related to digital detox, considering one of the most important factors affecting the choice of destination in tourism is the price and the other is the destination, are understood to be related to digital detox tourism and is included under this heading for this reason (Sunar, et al. 2018). In his study, Sousa (2017) aimed to examine the phenomenon of digital detox among tourists from different nationalities, mostly Portugal, and to understand whether people really want to disconnect, and found that the participants did not prefer a digital detox vacation and the reasons for this were fear of not being available in an emergency and social media addiction. In the study 
conducted by Sutton (2019), it has been revealed that people involved in digital detox tourism get rid of the pressure and burnout caused by continuous internet use and feel more comfortable as they move away from this pressure. At the same time, it has been observed that people who make this type of travel feel freer and enjoy themselves in a very comfortable way when they do digital detox. Another situation observed in people who are away from digital and technological devices is that they can socialize more easily and feel comfortable while communicating. In the study prepared by Can Çulcuoğlu and Erbil (2019) to detect the intention of people living in Turkey to participate in the digital detox tourism, it was determined that the participants give more space for activities to reduce the use of digital in their daily life, while on the other hand during their travels they choose not to participate in activities that restrict the use of digital devices. In the study, a statistically significant difference was found between the level of dependence on digital devices and the perception of digital detox need factor and age. Accordingly, digital device addiction increases with age. In addition, there is a significant difference between the factor of restricting the use of digital devices while on vacation and/or travel and both gender and marital status. Women show more restrictive action than men, and married people show more restrictive action than singles. Egger, Lei and Wassler (2020) investigated the factors that drive individuals to digital detox tourism, and the travel motivations of individuals who adopt digital detox tourism; they determined them to be escape, personal growth, health and well-being, and relationships.

Based on the findings, it can be said that digital detox tourism reduces stress levels, increases mental positivity and improves social interactions. Digital detox holidays may include any of the following activities; reading, cycling, hiking, yoga, spa, fishing, sailing, arts and crafts, wine tasting, picnic, photography, and cooking (Francis, 2017; traveltalkmag.com). The main purpose on the other hand, is to provide the opportunity to get rid of the addiction created by technology, and it provides people with the opportunity to return to their essence and nature.

When the applications for digital detox tourism are examined today it can be seen that some luxury travel businesses help their customers to get away from technology, for example; Black Tomato offers customers the opportunity to get lost in unknown places with the "Mystery Tour" option. During these tours, the Black Tomato company uses high technology to ensure that its customers reach their destination safely. Some vacation sites appear to be trying to help customers with technology addiction in other ways. For example, Digitaldetoxholidays with the slogan "Disconnect to Reconnect!" designed as a site that carefully selects hotels that offer detox holidays without $\mathrm{Wi}-\mathrm{Fi}$, phones, or even TV for travelers who want to relax (www.verdict.co.uk). The hotels offering detox survival kit (breakfast in bed, relaxing candles, yoga, massage, spa, etc.) option in a luxurious environment also offer activities such as walking trails, boat tours, and tree planting outside the hotel. Examples of the best hospitality businesses in the world implementing digital detox tourism are: Westin Dublin, Ireland; Grand Cayman Marriott, Cayman Islands; Echo Valley Ranch \& Spa, Canada; Palm Island Resort, Grenadines; Kimpton Monaco, Chicago, USA; Four Seasons on the Papagayo Peninsula, Costa Rica; Renaissance Pittsburgh, USA; JW Marriott Cancun, Mexico; Lifehouse Spa and Hotel, Essex, United Kingdom; Jakes, Treasure Beach, Jamaica (Sousa, 2017).

\section{Conclusion and Recommendations}

Today, people attribute meaning and importance to devices such as smartphones that define the level of socialization and interactions with it. Among the reasons for this is the ability of smartphones to take pictures, play music, give driving coordinates, collect information, play games, as well as make phone calls and send text messages. However, the excessive and irrational importance that individuals give to these devices increases the risk of addiction and reduces the quality of life. Nevertheless, it has been observed that some people are unwilling to opt for digital detox because of the fear of being disconnected from the social connection established through social media channels and fear of being out of reach and not being able to reach out in case of an emergency. On the other hand, it is an undeniable fact that the problem of over-dependence on technology has become an increasing problem throughout the world and awareness of the negative effects of this addiction is increasing.

Transferring the need for digital detox to the holiday experience of the people and thus providing a kind of technological purification during the holiday periods can be called "digital detox tourism". In other words; if detox is considered as a radical decision for people to stop taking harmful foods, drinks or medicines into their bodies in order to be healthier; digital detox tourism can be 
considered as a "treatment method" that aims to keep people away from the harmful effects of the technology addiction. In recent years, where the exhibition of a holiday on social media has been observed at very high levels, digital detox, which can be considered as the opposite, taking a vacation only for pleasure, ignoring the opinions of others, and living in the moment instead of taking photos, and getting away from the intensity of daily life. Research states that there are people who think that it is wrong to restrict the use of technology during vacation, but there are quite a lot of people who prefer to get away from the digital and social media during vacation (Tribe \& Mkono, 2017; Chen, et al, 2018).

It is possible and even necessary to consider digital detox tourism as a new alternative form of tourism in today's world where holidays offering digital detox opportunities are on the rise with a rapid acceleration. So much so that as the inclusion of technology in human life increases, it is thought that the interest in holidays and travels where digital detox is applied will increase. In this context, it is estimated that it will become more popular in the coming periods and has the potential to become an important tourism branch. In addition, due to the COVID-19 Pandemic, which emerged in Wuhan, China in December 2019 and turned into a global health crisis in 2020, the amount of face-to-face meetings, the amount of people working in the same environment, the number of face-to-face events has gradually decreased. These were replaced by sharing and activities in virtual environments. With the increase in virtual sharing and activities, the rate of using technological devices has naturally increased. It is thought that this situation, which is thought to be going to progress in this way in the long term, will cause people to get tired of technological devices with the increasing cognitive and physical negative effects and this will strengthen the desire to get away from them.

Considering all these reasons, in the near future the number of accommodation businesses implementing digital detox tourism applications will increase, and the number of travel agencies and tour operators that will organize tours for digital detox tourism will increase as well. To put it more briefly, it is predicted that tourism stakeholders will carry out intensive studies on the subject in destinations suitable for digital detox tourism. As the studies intensify in the practical part of the tourism sector, the academic dimension that shapes the theoretical part of tourism should not fall behind. In this context, it is thought that digital detox tourism should also be included under the heading of "tourism types according to the methods and purposes" included in general tourism and introduction to tourism books. This concept should be included in the tourism literature and should be considered as an alternative tourism type with a very high future potential.

When digital detox reaches a conceptually recognizable position in related literature, it is thought that research made on the subject will increase. In the aforementioned future research, especially for destination marketers and managers, studies emphasizing the importance of digital detox tourism, and research on the relationship between digital detox tourism with different variables (behavioral intentions, tourist satisfaction, tourist motivation (push and pull), tourist experience, etc.) will contribute to the literature.

\section{References}

APA (2013). American Psychiatric Association, Diagnostic and statistical manual of mental disorders (5th ed).

Bailey, K. D. (1982). Methods of social research (2nd ed.). New York: Free Press.

Best, J. W. (1959). Research in education. New Jersey: PrenticeHall, Inc.

Bilici, N. (2011). Modernite ve postmodernite yeniden. http://www.agos.com.tr/tr/yazi/104/modernite-vepostmodernite-yeniden. (Access Date: 26.12.2019).

Blom, T. (2000). Morbid tourism-a postmodern market niche with an example from Althorp. Norsk Geografisk Tidsskrif, 54(1), p. 29-36.

Booth, F. (2015). Do you need a good excuse to do a digital detox?http://www.forbes.com/sites/francesbooth/2015/0 3/05/do-you-need-a-good-excuse-to-do-a-digital-detox/. (Access Date: 24.11.2019).

Bozok, D., Açıksözlü, Ö., Şahin, N. N., \& Varol, İ. (2014). Turistlerin kişilik özellikleri ile postmodern turizme eğilimleri arasındaki ilişkiyi incelemeye yönelik bir araştırma - Balıkesir ili örneği. 9th International Conference: New Perspectives in Tourism and Hospitality, (pp. 849-871). Burhaniye.

Campbell, S., \& Kwak, N. (2011). Mobile communication and civil society: Linking patterns and places of use to engagement with others in public. Human Communication Research, 37, p. 207-222.

Can, İ. I., Çulcuoğlu, S., \& Erbil, E. (2019). Türkiye'de dijital detoks algisı ve turizmin bir dijital detoks aracı olarak değerlendirilmesi. VI.Yıldız Sosyal Bilimler Kongresi (pp. 1521-1537). İstanbul: Yildız Teknik Üniversitesi.

Chen, C. C., Huang, W. J., Gao, J., \& Petrick, J. F. (2018). Antecedents and consequences of work-related smartphone use on vacation: An exploratory study of 
Taiwanese tourists. Journal of Travel Research, 57(6), p. 743-756.

Dickinson, J. E., Hibbert, J. F., \& Filimonau, V. (2016). Mobile technology and the tourist experience: (Dis)connection at the campsite. Tourism Management, 57, p. 193-201.

Dinçer, F. İ., Can, İ. I., \& İnan, B. (2018). Post-Modern turizm paradigması etrafinda şekillenen gerçek üstü bir deneyim: Uzay turizmi. Güncel Turizm Araştırmaları Dergisi, 2(1), p. 79-93.

Dujmović, M., \& Vitasović, A. (2015). Post-modern society and tourism. Journal of Tourism and Hospitality Management, 3(9-10), p. 192-203.

Duncan, B. M. (2014). Digital detox, mindfulness, and art museums. Drexel University. Drexel: USA.

Egger, I., Lei, S. I., \& Wassler, P. (2020). Digital free tourismAn exploratory study of tourist motivations. Tourism Management, 79, 104098

Fan, D. X., Buhalis, D., \& Lin, B. (2019). A tourist typology of online and face-to-face social contact: Destination immersion and tourism encapsulation/decapsulation. Annals of Tourism Research, 78, p. 1-16.

Feifer, M. (1985). Going places: The ways of the tourist from imperial Rome to the present day. New York: Macmillan Publishers.

Firat, F., \& Shultz, C. J. (1997). From segmentation to fragmentation: Markets and marketing strategy in the post-modern era. European Journal of Marketing, 31(3/4), p. 183-207.

Francis, G. (2017). Irresistible: Why we can't stop checking, scrolling, clicking and watching review.https://www.theguardian.com/books/2017/feb/26 /irresistible-why-cant-stopchecking-scrolling-clickingadam-alter-review-internet-addiction. (Access Date: 29.12.2019)

Giddens, A. (1990). The consequences of modernity. Cambridge: Polity Press.

Güneren, E., \& Karakuş, Y. (2015). Turizmde postmodern pazarlama. In B. Kılıç \& Z. Öter (Eds.), Turizm pazarlamasında güncel yaklaşımlar. Ankara: Beta Yayım Dağıtım.

Güzel, F. Ö. (2014). Postmodern çağ tatil deneyimlerinde hazcı tepki basamağı çıtısı olarak temalı oteller. International Journal of Economic and Administrative Studies, 7(13), p. 1-15.

Haber, M. (2013). “A trip to camp to break a tech addiction,” New York Times (5 July), at http://www.nytimes.com/2013/07/07/fashion/a-trip-tocamp-to-break-a-tech-addiction.html. (Access Date: 20.11.2019)

Hoving, K. (2017). "Digital detox tourism: Why disconnect? What are the motives of Dutch tourists to undertake a digital detox holiday?" Master Thesis. Umeå Universitet. Department of Geography and Economic History. Umeå: Sweden. https://www.flogas.co.uk/news/tech-free-tourism. Tech-free tourism: The rise of digital detox holidays. (Access Date: 29.12.2019).

https://www.traveltalkmag.com.au/blog/articles/the-rise-ofdigital-detox-holidays-and-tech-free-tourism (Access Date: 30.12.2019).

https://www.verdict.co.uk/digital-detox-holidays/ Is the digital detox of holidaymakers becoming travel companies' problem? (Access Date: 29.12.2019)

Karasar, N. (2005). Bilimsel araşstırma yöntemi. (15. Baskı) Ankara: Nobel Yayın Dağıtım

Kardaras, N. (2016). Generation Z: Online and at risk? Scientific American Mind, 27(5), p. 64-69.

Kıral, B. (2020). Nitel bir veri analizi yöntemi olarak doküman analizi. Siirt Üniversitesi Sosyal Bilimler Enstitüsü Dergisi, 8(15), p. 170-189.

Kozak, M. A., Evren, S., \& Çakır, O. (2013). Tarihsel süreç içinde turizm paradigması. Anatolia: Turizm Araştırmaları Dergisi, 24(1), p. 7-22.

Li, J., Pearce, P. L., \& Low, D. (2018). Media representation of digital-free tourism: A critical discourse analysis. Tourism Management, 69, 317-329.

Lyotard, J. F. (1997). The post-modern condition. Manchester: Manchester University Press.

Magee, A. (2016). "Help! I need a digital detox," http://www.telegraph.co.uk/wellbeing/mood-andmind/help-i-need-a-digital-detox (Access Date: 10.12.2019).

Merriam, S. B. (1988). Case study research in education: A qualitative approach. San Francisco: Jossey-Bass.

Murphy, S. (2011). Tech withdrawal similar to giving up drinking, smoking. Tech News Daily.

Muzaini, H., Teo, P., \& Yeoh, B. S. (2007). Intimations of postmodernity in dark tourism: The fate of history at Fort Siloso, Singapore. Journal of Tourism and Cultural Change, 5(1), p. 28-45.

Nuryanti, W. (1996). Heritage and postmodern tourism. Annals of Tourism Research, 23(2), p. 249-260.

Odabaşı, Y. (2006). Postmodern pazarlama. İstanbul: Mediacat Yayınlar1.

Pearce, P. L., \& Li Jing, L. (2018).The rise of the 'digital detox' holiday: The trend changing the way we take a break. https://www.smartcompany.com.au/industries/tourism/th e-rise-of-the-digital-detox-holiday-the-trend-changingthe-way-we-take-a-break/. (Access Date: 29.12.2019).

Quan, S., \& Wang, N. (2004). Towards a structural model of the tourist experience: An illustration from food experiences in tourism. Tourism Management, 25(3), p. 297-305.

Rainie, L., \& Zickuhr, K. (2015). “Americans' views on mobile etiquette.” Pew Research Center. August, 2015.

Reed, L. (2002). Governing (through) the Internet: The discourse on pathological computer use as mobilized knowledge. European Journal of Cultural Studies, 5(2), p.131-153. 
Sağıroğlu, M. (2019). Turistik mekânda gerçekliğin algısal değişimi: Modern ve post-modern turizm deneyimlerinde özgünlük. Planlama, 29(2), p. 90-101.

Sallan, S., \& Boybeyi, S. (1994). Postmodernizm - modernizm ikilemi. Ankara Üniversitesi Dil ve Tarih-Coğrafya Fakültesi Felsefe Bölümü Dergisi, p. 313-323.

Smith, M. (2003). Holistic holidays: Tourism and the reconciliation. Tourism Recreation Research, 28(1), p. 103-108.

Smith, M., \& Puczkó, L. (2015). More than a special interest Defining and determining the demand for health tourism. Tourism Recreation Research, 40(2), p. 205-219.

Sousa, B. M. D. D. (2017). Digital detox (Doctoral dissertation). UE - Universidade Europeia. Lisbon.

Sunar, H., Gökçe, F., \& Cihangir, İ. S. (2018). Turizmde yeni bir yaklaşım: Dijital arınma. N. Bilici, R. Pehlivanlı, \& K. Ashirkhanova (Ed.), Innovation and Global Issues in Social Sciences Congress (p. 326-338). Antalya: InGlobe.

Sutton, T. (2019). Disconnect to reconnect: The food/technology metaphor in digital detoxing. First Monday, 22(6), 1p. https://doi.org/10.5210/fm.v22i6.7561.
Syvertsen, T., \& Enli, G. (2020). Digital detox: Media resistance and the promise of authenticity. Convergence, 26(5-6), $1269-1283$

Tribe, J., \& Mkono, M. (2017). Not such smart tourism? The concept of e-lienation. Annals of Tourism Research, 66, p. $105-115$.

Urry, J. (1990). The tourist gaze. London: SAGE Publications.

Urry, J. (2009). Turist bakışı. Ankara: Bilge Su Yayıncılık.

Yıldırım, A., \& Şimşek, H. (2013). Sosyal Bilimlerde Nitel Araştırma Yöntemleri. (9. Genişletilmiş Baskı) Ankara: Seçkin Yayınevi.

Wang, D., Xiang, Z., \& Fesenmaier, D. (2014). Adapting to the mobile world: A model of smartphone use. Annals of Tourism Research, 48, p. 11-26.

White, T. R. (2013). Digital social media detox (DSMD): Responding to a culture of interconnectivity. In Social media and the new academic environment: Pedagogical challenges (pp. 414-430). IGI Global. 


\title{
INFO PAGE
}

\section{Digital detox tourism against post-modernity}

\begin{abstract}
Technology has become an integral part of daily life. Although developments in the digital world offer many advantages to users, researches show that the use of smart devices is rapidly turning towards a kind of an addiction (digital addiction) in every field. In such unwanted situations, people try to apply a kind of a purification program by staying away from technological devices for a certain period of time with "Digital Detox". Transferring the need for digital detox to people's holiday experience and thus providing a kind of a technological purification during the holiday periods can be called "Digital Detox Tourism". Digital detox tourism, which is against postmodernism, attracts attention as a type of tourism preferred by individuals who seek diversity and have different expectations, especially those who want to stay out of intensive technology-based tourism activities. Perceived as fairly new concept in literature that has emerged as a result of the changing tourists expectations, establishing the theoretical infrastructure of digital detox tourism on the axis of post-modernism, evaluating the factors that caused the emergence of digital detox tourism, examining the factors that drive people to digital detox tourism and examination of theoretical and practical work about digital detox tourism; constitute the aim of this study. This study is aimed at researchers and target marketing organizations as it offers valuable conclusions that help better understand the emotions of individuals who are involved in or are avoiding digital detox tourism. Understanding what triggers positive and negative emotions of individuals is thought to help service providers develop their products and marketing strategies.
\end{abstract}

Keywords: Digital detox, Digital detox tourism, Alternative tourism, Post-modernism

\section{Authors}

Full Name Author contribution roles

ipek Itır Can: Conceptualization, Writing - Original Draft, Writing - Review \& Editing,

Contribution rate

Nurhayat Iflazoglu: Resources, Writing - Original Draft, Writing - Review \& Editing,

Author statement: Author(s) declare(s) that All procedures performed in studies involving human participants were in accordance with the ethical standards of the institutional and/or national research committee and with the 1964 Helsinki declaration and its later amendments or comparable ethical standards.

Ethics Committee Satatement: This paper does not required ethics committee report. 